\title{
William Schaw Lindsay: righting the wrongs of a radical shipowner
}

\section{Michael Clark}

William Schaw Lindsay a perdu ses parents en 1825 à l'âge tendre de dix ans, il s'est enfui en mer en 1831 et il est rentré à terre âgé de vingt-cinq ans et certifié comme maître de bord. Il est devenu courtier de navires et a exploité les caprices du marché marin à la suite de l'abrogation des lois sur la navigation pour devenir armateur, établissant une compagnie de navigation spécialisée dans l'émigration vers l'Australie et affrétant des navires aux gouvernements français et britannique pendant la guerre criméenne. Élu député au parlement en 1854, il a favorisé les issues maritimes mais sa sympathie publique envers les États Confédérés pendant la guerre civile l'a mené vers des accusations que ses bateaux cassaient le blocus des États-Unis.

\section{Introduction}

"His family details are sketchy..."1

For a century and a half, many wrongs have been written about William Schaw Lindsay and this paper will attempt to clarify how and why he has been misrepresented. The Oxford Dictionary of National Biography claims that his family details are sketchy yet Lindsay was proud of his lowly origins and never concealed them. He was born during a gale on 19 December 1815 at the manse of his uncle, the Reverend William Schaw, in the county town of Ayr in South-West Scotland. ${ }^{2}$ Tragically, Lindsay's father died four years later, followed by the death of his mother in 1825 and Lindsay wrote "From that moment I felt I was a child of poverty whose lot was to earn my bread by the sweat of my brow." " 3 The childless minister and his wife willingly took Lindsay into the manse and sent him to Ayr Academy in the hope that he would become a Free Church minister like himself. In 1831, however, Lindsay, aged fifteen, left this happy home and headed for Glasgow in the vain hope of settling with his siblings. The Oxford Dictionary

1 Oxford Dictionary of National Biography, vol. 33 (Oxford: Oxford University Press, 2004), 906 (hereinafter $O D N B$ ).

2 Ayr was Robert Burns' "town of honest men and bonnie lassies."

3 William Schaw Lindsay's unpublished Journal, Greenwich, UK, National Maritime Museum, LND/5/1-4 vol. 1: 1 (hereinafter LND).

The Northern Mariner/le marin du nord, XX No. 3, (July 2010), 283-311 
of National Biography claimed that Lindsay inclined to a seafaring life but it was only after a few months, when he again felt that he was nobody's child, that he put together a small bundle of possessions and started out for Glasgow docks. The master of a Liverpool-bound steamer took all his capital of five shillings as partial fare and sent him down to the engine room to work off the balance by trimming coal for the furnace. As Lindsay was quitting the vessel in Liverpool, the master returned all the money to him because he had worked so hard. "That was one of the proudest moments I had ever up to then experienced. I had not only worked for my dinner but worked for my passage too." ${ }^{\prime 4}$

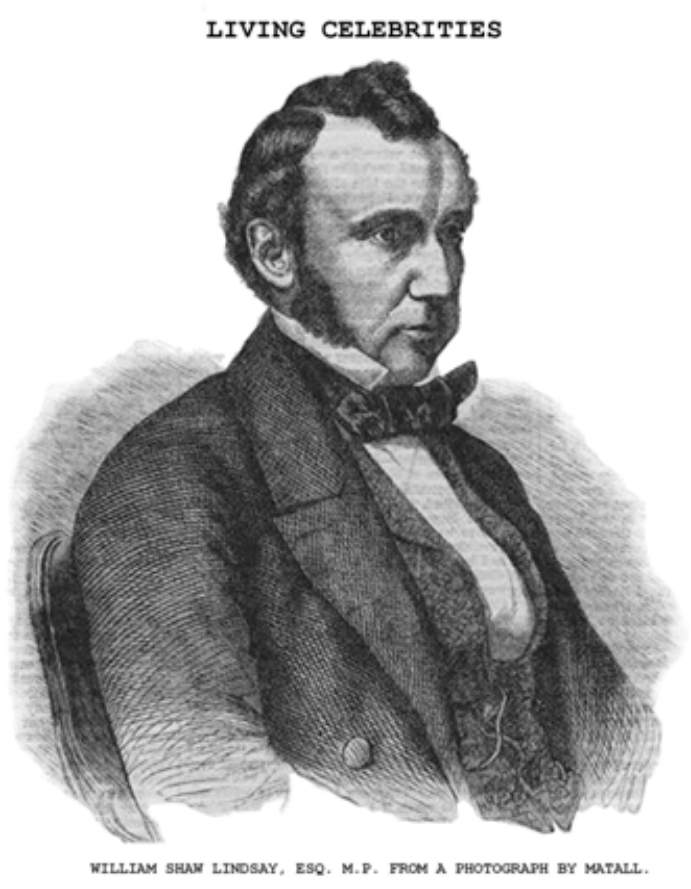

Illustration 1: William Schaw Lindsay, after John Jabez Edwin Mayall (nee Jabez Meal), 1859, donated to the National Portrait Gallery by Henry Witte Martin, 19 October 1861. National Portrait Gallery (NPG D21246).
During six weeks Lindsay visited every ship in the Liverpool docks seeking work, sleeping in cargo sheds and begging for halfpennies and bread to stay alive. On his fourth attempt to obtain employment in the 337-ton Isabella, owned by a Glasgow-based West India merchant George Anderson, he was taken on as cabin boy and offered a four-year apprenticeship. During a storm, Lindsay was washed overboard and picked up for dead having suffered two broken ribs and a broken thigh with the bone protruding through the flesh - but not both legs and an arm as reported in the Oxford Dictionary of National Biography. When he signed off the ship in London in 1834, Anderson took him to the London Hospital to reset the damaged leg and gave him $£ 5$ to tide him over, an act of kindness which Lindsay later reciprocated. He next joined the 320-ton East India trader Olive Branch, owned by a Mr Greenwell of Sunderland, initially for one voyage as chief mate but within a year he was the master and a "petty tyrant due to a temper which could brook no

control." Ashore at Bushire in 1839, he was wounded by a sabre when attacked by thieves but managed to shoot one of them dead. In the following year, Lindsay retired from the sea, aged twenty-five, and Greenwell, who owned the Castle Eden Coal Company, offered him a post as port agent in Hartlepool at $£ 150$ per annum. ${ }^{6}$ The Oxford Dictionary of National Biography calls him a "fitter" — an obsolete term for a coal agent.

\footnotetext{
$4 \quad$ LND/5/1-4 vol. 1: 16-19.

$5 \quad$ LND/5/1-4 vol. 1: 20-26, 28-30, 71-76, 161-163, 174.

$6 \quad$ LND/5/1-4 vol. 1: 298, 324.
} 


\section{One - Shipbroker}

"from cabin-boy to MP by way of merchant prince..."7

Lindsay's strenuous efforts to develop Hartlepool as an independent port resulted in a new lighthouse on the Heugh being known by local pilots as Lindsay's Light. ${ }^{8}$ He built up an extensive circle of shippers for Castle Eden's coal in less than six months, despite its poor quality. On his own initiative, Lindsay contacted a Glasgow iron master, Robert Stewart, who was having difficulty selling pig iron in north-east England at his price of 55 shillings per ton. Lindsay's efforts managed to sell 500 tons at 57/6d, earning a one percent commission for Castle Eden. In November 1843 Lindsay married Stewart's sister Helen in Glasgow and within two years he had doubled not only Castle Eden's coal sales but Stewart's pig iron as well. In 1845, Greenwell proposed that Lindsay should go to London to market their coal and sell pig-iron on his own account. As Lindsay noted in his journal, "There goes that Scotchman awa' farther South, catch him coming North again."9

It was not a good time to start afresh. A financial crisis in 1848 and the British government's resolve to repeal the Navigation Laws had created a mood of "sullen, sulky, stubborn gloom" 10 amongst shipowners as it was expected that three-quarters of them would be ruined. Lindsay deplored the existing act being abandoned abruptly instead of in stages and that the issue had become one of party so neither side would meet to discuss it. He had, however, two maxims: "work, work, work" and "do unto others as I would be done by" plus a tendency to work twelve hours a day. ${ }^{11}$ Coupled with what Liverpool shipowner Alfred Holt described as his "strange mixture of energy, industry, self-reliance, egotism [and] pretence," 12 Lindsay used his first-hand knowledge of ships to become a London shipbroker.

Shipbroking had a low barrier of entry as it required little or no capital and some three hundred members of the Baltic Committee offered their services to shipowners and merchants. ${ }^{13}$ Lindsay took an office at 35 Abchurch Lane and procured a directory of London coal merchants, only to learn that they always bought their coal directly from the market. One of his first contacts in London was Aberdeenborn James Allan, who had recently joined Brodie Willcox and Arthur Anderson, former partners in a small shipping commission business. They were part owners of a

$7 \quad O D N B$.

$8 \quad$ LND/5/1-4 vol. $1: 306-308$.

9 LND/5/1-4 vol. 1: 276, 278, 280-282, 284-285, 327.

10 Sarah Palmer, Politics, Shipping and Repeal of the Navigation Laws (Manchester: Manchester University Press, 1990), 177.

11 [William Schaw Lindsay], The Log of My Leisure Hours by an old sailor, 3 vols. (London: Sampson, Low, Son and Marston, 1868), 1: 63-64, 3: 187, 204 n.

$12 O D N B$.

13 Hugh Barty-King, The Baltic Story: Baltick Coffee House to Baltic Exchange 1744-1994 (London: Quiller Press, 1994), 14-15. 
few vessels which they had developed into the Peninsular and Oriental Steam Navigation Company and steam coal was one of their heaviest expenses, consuming as much as 90,000 tons in a year. Lindsay persuaded Allan to take two trial cargoes of Castle Eden's coal but P and O's policy was to buy coal only at the bunkering stations where it was to be consumed along the route to India and China. This allowed them to carry more revenue-earning freight, but Allan helpfully told Lindsay how much they would pay at those ports. ${ }^{14}$ Lindsay realised that to achieve these prices he had to find a novel way of freighting ships to transport the coal from Hartlepool and still earn him a commission. Each day he toured the London docks quoting captains the freight rate he would pay for their ship and, eventually, one accepted. Lindsay not only got his commission but managed to pocket a one-shilling per ton profit on the deal. ${ }^{15}$

Most shipping brokers in London, having trained in counting houses, knew very little about operating ships and only thirty-seven percent of the holders of shipping shares recorded in London registers for 1848 described themselves primarily as shipowners. ${ }^{16}$ Before long, the owners of the ships that Lindsay had been chartering as a broker soon found their way to his office to seek advice and talk about their vessels "as a mother does of her child." ${ }^{17}$ By dealing with him directly they not only saved paying an extra brokerage, thus keeping more of the freight for themselves, but they could discuss contract terms with the man who signed the charterparty.

Conservative shipowners often refused an outward freight if there was no guaranteed homeward cargo to avoid the expense of returning in ballast. Lindsay, therefore, scoured the market for return cargoes and earned a commission on both transactions. Regular shipbrokers, missing out on this business, assumed Lindsay must be speculating and gleefully predicted his imminent demise. However, before long they were offering him ships for charter and if their rates were more than the market would bear, they shared part of the brokerage with him as a sweetener. Lindsay's first year of innovative trading showed a profit of $£ 1,000$, the second year it doubled and by the third year he cleared $£ 3,000$. Lindsay now described his company as "the first shipbroker (by rank)" greatest number of chartering contracts in London. Each day his office was thronged by shipowners with charterparties, masters with manifests, sailors cashing advance notes and wives drawing their husbands' allowances.

Lindsay opened an agency in Sunderland, a town where almost every tradesman invested in ships, often beyond their means. A local cobbler put $£ 300$ in a

14 William S. Lindsay, History of Merchant Shipping and Ancient Commerce, 4 vols. (London, 1874-6), 4: 408-9.

$15 \mathrm{LND} / 5 / 1-4$ vol 2: 3, 5, 9, 11-12.

16 Palmer, Shipping, 12.

$17 \mathrm{LND} / 5 / 1-4$ vol 2: 15.

18 LND/5/1-4 vol. 2: 89. 
vessel chartered through this agency for a coal voyage to Marseilles and a return cargo of grain. When the grain was not available, the master took a loss making cargo to Newcastle, the mortgagee put the ship up for sale and the cobbler wrote to Lindsay's agency asking for $£ 100$ to liquidate the debt. Although he had no financial responsibility in the voyage, Lindsay sent the cobbler a cheque for $£ 170$ to cover the freight he would have earned had all gone well. Impressed, the cobbler repeated the story of Lindsay's generosity around Sunderland. "That act, meant simply as an act of charity to a poor industrious man, proved the grand cause of my rapid rise as a shipbroker in London." ${ }^{\prime 19}$ Within a week, local shipowners authorised Lindsay to find employment for eleven ships. He quickly found a cargo of grain from America to the Mediterranean for each one at high freights that would have earned $£ 400$ commission on each successful fixture. However, suspecting that the grain merchants would not have sufficient resources if the market dropped, Lindsay returned the authorities to the shipowners without chartering out their vessels. The owners, believing this highly unusual act for a shipbroker had lost them a good deal, fixed the cargoes through other brokers. After only one ship had loaded, grain prices did fall, the merchants went bankrupt and the remaining ships ran up huge losses, but Lindsay's reputation grew. The Sunderland owners placed all their business exclusively in his hands and Baillie Mitchell of Glasgow gave him sole commercial control of ten 700- to 1,000ton ships. Even Lindsay's old command, Olive Branch, now owned by a merchant in Stockton, earned him many commissions until it was lost at sea a few years later.

An important function of a shipbroker was to ensure that a cargo was released to the holder of the Bill of Lading, the title to the goods, only after freight had been paid to the shipowner. During times of economic and financial hardship, large merchant houses pressed agents to deliver goods against their promise to pay two months hence which encouraged market speculation and most banks and discount brokers rejected Bills marked "on account of freights." Lindsay risked losing the support of major merchants like Anthony Gibbs and Overend Gurney by refusing to waive the rules and release cargoes under his agency without a proof of ownership or a financial guarantee. ${ }^{20}$ Even when the former owner of Isabella, George Anderson, visited Lindsay, who he did not recognise, and offered payment in two months on a consignment of sugar, Lindsay explained that he could not deviate from the established rules. Instead, he wrote a cheque for $£ 1,500$ for Anderson to pay to his bankers, took Anderson's cheque for the freight and released the cargo, saying "one good turn deserves another, repay me when convenient." He then reminded the puzzled Anderson about the second mate known as "Glasgow" on Isabella two decades earlier who Anderson had taken to hospital and given £5. It was, as Lindsay noted in his journal, "a curious but not unpleasing incident in my chequered but prosperous life." 21

\footnotetext{
19 LND/5/1-4 vol. 2: 17-19.

20 LND/5/1-4 vol. 2: 20, 29-30, 33-39 and 212.

$21 \quad \mathrm{LND} / 5 / 1-4$ vol. $2: 37$.
} 


\section{Two - Shipowner}

"one of the largest shipowning concerns in the world"22 "with, at one stage, 220 vessels in its fleet." 23

Records show that where Lindsay claimed to own a ship, he did, but this amounted to fewer than a dozen vessels at any one time and never as many as his contemporaries Alfred Holt, Booth, Swire or Alfred Jones. ${ }^{24}$ As a shipbroker, he was as interested in a vessel's technical innovation as its earning power and he invested in a token number of $64^{\text {th }}$ shares in some client's vessels, risking other owners' suspicion that he might divert lucrative cargoes to those vessels. A descendent wrote in 1983 that W. S. Lindsay \& Co. had owned about 20 ships with some shares held by a friend, family member, master, or a shipbuilder as security for a new vessel. ${ }^{25}$ By spreading his shareholdings he would never earn the maximum profit in boom times but equally he was protected from losing everything during the more common slumps — a tactic still employed by shipbrokers and owners today.

In October 1848, Lindsay agreed an exclusive brokerage with William Pearce of Liverpool on cargoes of iron carried on American vessels. ${ }^{26} \mathrm{He}$ also took a partner five years his junior, Edgar Pinchback Stringer, to whom he ceded one third of W. S. Lindsay $\& \mathrm{Co}^{27}$ As business expanded, the office moved to larger premises at 8 Austin Friars where they were joined by a former colleague from Hartlepool, the "knowledgeable and equally hard-working" John Gladstone. Lindsay predicted that within five years the strain placed on British shipping by the recent discovery of gold in California and Australia would hasten the shift from wood-built sailing vessels to faster and more reliable iron screw steamers. ${ }^{28}$ In April 1850, Alexander Scott of Greenock began selling off surplus ships cheaply blaming 'the ruinous effect' of the repeal of the Navigation laws. ${ }^{29}$ In the course of one week, Lindsay contracted eight iron-built ships of 800 register tons, two each from Scott and yards in Sunderland, Cumberland and Jersey, putting him at the forefront of steamship development. ${ }^{30}$ Although two orders were cancelled, reports of

22 Dictionary of National Biography (London, 1893), 316-317.

$23 O D N B$.

24 Palmer, Shipping, 110.

25 Ronald McKie, The Age, 2 April 1983. He claimed that the company may have chartered up to 700 ships.

26 Morning Chronicle, 16 November 1859, 1. It ended in breach of contract in Court of Chancery.

27 LND/5/1-4 vol. 2: 112-115. Born 1821, he became the active partner in 1855 and died in Brighton in 1894.

28 Lindsay History of Merchant Shipping, 3: 93-109.

29 Glasgow University Archive, Scott Papers, GD319 II///18, Scott to Beattie 13, April 1850. Also Sarah Palmer, "The British Shipping Industry 1850-1914," in Lewis R. Fisher and Gerald E. Panting, eds., Change and Adaptation in Maritime History: The North Atlantic Fleets in the Nineteenth Century (St John's: Maritime History Group, 1985), 91 and 178.

LND/5/1-4 vol. 2: 192-193; the ships were Alipore, Barrakpore, Cossipore, Dinapore, 
these counter-cyclical purchases left other shipowners wondering what Lindsay knew that they did not but, by the time they reacted, a twenty-five percent rise in ship values had made Lindsay rich, at least on paper. It was not the last time a quick-witted individual shipowner outsmarted the established shipping companies run by committees of wealthy merchants.

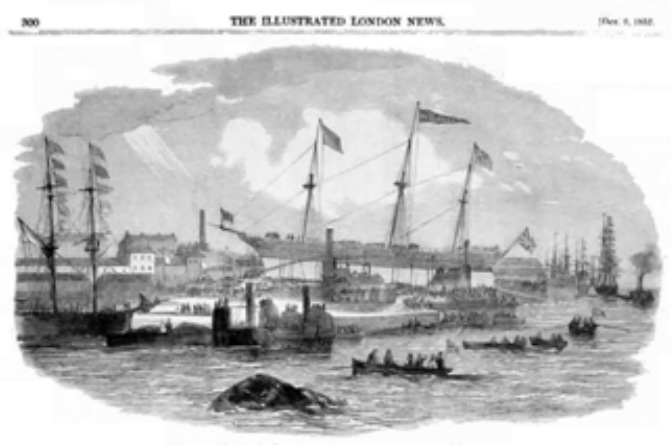

Illustration 2: Launch of Ship W. S. Lindsay. Illustrated London News, 9 October 1852. Credit: Public Domain.
In 1852, Lindsay ordered the largest iron-built vessel to date. At 900 tons, the eponymous $W$. S. Lindsay, from Coutts \& Parkinson of Tyneside, was longer and wider "to take advantage of the rapid advance in free-trade." 31 Designed for the Australian immigrant trade, it cost one-third more than similar vessels but was three times more efficient with 280 cabins including sixty for first class passengers. Lindsay held 54 of the 64 shares in the ship, giving the other ten to the master, George Western. ${ }^{32}$ On 31 July 1852, Lindsay \& Co. advertised the sailing of five chartered and owned passenger ships from London's St Katherine Dock to Melbourne, Geelong or Port Philip. ${ }^{33}$ On its maiden voyage in December, and carrying 300 passengers, $W$. S. Lindsay heeled over on the Downs during a storm and was towed back to London at a cost of $£ 3,000$. Lindsay compensated the passengers with another $£ 3,000$ for expenses and offered them alternative passages on the American ship James L Bogart. He was immediately summonsed to the Guildhall Court for entering into a contract to provide passages for $£ 10$ each and not supplying an equally eligible ship within ten days. The magistrates, however, dismissed the case, stating that Lindsay's conduct had been "under the circumstances of a nature highly honourable to him. " ${ }^{34}$ James L Bogart sailed on 10 January 1853.

A Liverpool shipowner had ordered a similar but larger vessel than W. S. Lindsay from the same yard and chartered it to Lindsay \& Co. Named Swarthmore, it cost almost $£ 20,000$ to build, but "Government naval architects" declared it unseaworthy on the grounds that "the construction [carried] elements of ruin ... unless considerable

\section{Mirzapore and Serampore.}

31 David R. MacGregor, Merchant Sailing Ships 1850-1875: Heyday of Sail (Annapolis, MD: Naval Institute Press, 1984), 31.

32 LND/5/1-4 vol. 2: 182-185; Kew, UK, The National Archives (hereinafter NA), Register of Transactions, BT107/107, 427/52, 97/53.

33 Moselle 650 tons 10 August, Alipore 1350 tons 5 September, Janet Mitchell 1300 tons 20 September (commanded by Greenock-born Thomas Fisher; in January 185323 seamen deserted at Melbourne to join the gold rush), Barrackpore 1350 tons 5 October, W.S. Lindsay 1100 tons 1 November. The Scotsman, 31 July 1852, 3. 
alterations are made." ${ }^{35}$ Once again Lindsay's office was thronged by disappointed passengers demanding an alternative vessel but Swarthmore eventually sailed for Australia without any structural changes. ${ }^{36}$ On the homeward leg, it put into Tahiti in distress and on return to Britain, the spar deck was removed. ${ }^{37}$ Lindsay was convinced that his public criticism of the government's attitude to the shipping industry and on manning the Royal Navy had made him enemies and that these incidents were politically motivated.

In February 1853, Lindsay contracted two iron steamers with $80 \mathrm{hp}$ auxiliary engines and innovative retractable screw propellers. One, Robert Lowe ${ }^{38}$ from Scott at an invoice price of $£ 17,000$, was launched eighteen months late and Lindsay withheld the final payment as compensation. Scott counterclaimed $£ 2,685$, blaming the delay on Lindsay's indecision over their alternative designs to comply with his demand for a vessel "to carry a regiment of 1,000 men" and with the capacity of a three-decker but the tonnage of a two-decker. Lindsay, though, believed the delivery had been unjustifiably delayed because it could now be sold for $£ 20,000$. He eventually settled the payment on condition that Scott donated $£ 100$ to a Glasgow charity for the poor. The local press reported that Scott's slipway, made of new pitch pine, was set alight by friction from the ship's weight which turned the grease into glue preventing the vessel reaching the water for three days. However, on casting off the tug at Ailsa Craig, it steamed off at an impressive $51 / 2$ knots. ${ }^{39}$ Lindsay later claimed that he paid $£ 60,000$ for the two vessels when the cost of labour was low, but were worth $£ 80,000$ and "the best investment I ever made." 40

Lindsay broke his hard won contract to supply coal to P \& O in January 1853 , on the dubious grounds that there were no suitable ships available as they were either fixed to Australia or lacked crews to sail them away. ${ }^{41}$ The real reason was that the demand for ships in the Crimea had pushed up freight rates to the Far East by 34 per cent. ${ }^{42}$ Lindsay's failure to honour his contract was a disaster for $\mathrm{P} \& \mathrm{O}$ which was still bound by its eight year mail contract. ${ }^{43}$ Lindsay's emigrant trade, now dignified by the title of a Line of Packets from London to Australia, was also booming and he advertised the next three months' sailings of 'these ten first-class, British-built ships (all but one owned by

35 Sir Charles Wood, Speeches of ... Sir Charles Wood...in reply to certain charges made by William S. Lindsay ... against the conduct of the Lords Commissioners of the Admiralty ...June 22, and...July 10, 1855 (London: Woodfall and Kinder, 1855), 15.

LND/5/1-4 vol. 2: 185-190.

37 MacGregor, Merchant Sailing Ships 1850-1875, 32.

38 LND/1129; named after a rising MP for Kidderminster and secretary of The Board of Control.

39 Greenock Advertiser, 15 August 1854.

40 LND/5/1-4 vol. 2: 196, and vol 3: 7.

41 Lindsay to P \& O, 27 January 1853.

42 Martin Stopford, Maritime Economics (London: Routledge, 2009), 756.

43 Boyd Cable, A Hundred Year History of the P \& O... 1837-1937 (London: Nicholson and Watson, 1937), 136. 
Lindsay) fitted with every modern amenity": ${ }^{44}$

The undersigned having taken a deep interest in the trade to Australia [by] establishing an agency at Melbourne, and by employing some of the finest ships in this rapidlyincreasing passenger traffic to that port, offer to those who desire to proceed to that flourishing colony a most favourable opportunity. Every possible attention will be paid to the health, comfort, and convenience of the passengers. Libraries will be on board each ship, and rules established to maintain order and cleanliness. ${ }^{45}$

Those who claimed that Lindsay was the largest shipowner in the world perhaps confused him with a contemporary, shipbroker Edward Oliver of Liverpool. In 1854, Oliver had gambled that the demand for ships to transport troops and supplies to the Crimea would result in a rise in the freight market and assembled a fleet of ninety-eight ships, many exceeding 1,000 tons, of which he was the sole owner of seventy-five. ${ }^{46}$ In just one week he bought over thirty sailing vessels, some of which only four years earlier were worth $£ 15$ per registered ton, that changed hands for record prices of $£ 27$ per ton. Oliver's fleet exceeded that of any individual in any country, but to pay for it he had accumulated an enormous debt from eighty-four individuals, mainly other shipbrokers and owners. However, an oversupply of ships caused the freight market to fall by twothirds and the value of Oliver's fleet dropped by fifty percent. ${ }^{47}$ In December, with all his ships for sale, Oliver declared bankruptcy and suspended payments. ${ }^{48}$ Lindsay calculated that Oliver's liabilities amounted to $£ 857,313$ against assets of $£ 744,094$ leaving a deficiency of $£ 113,219$ and he predicted more speculators would fail. ${ }^{49}$

In 1856, financial losses put an end to the General Screw Steam Shipping Company's mail service to South Africa and the government arranged a new contract with Lindsay which stipulated a 36 day frequency for the voyages that now included India as well. He placed seven steamers and sailing vessels in the trade but after just thirteen voyages it was clear that the schedule could not be maintained as they were taking 50 to 60 days to complete the passage. ${ }^{50}$ In September 1857, Lindsay cut his losses and closed the service. ${ }^{51}$

44 The 1853 schedule: Helen Lindsay 900 tons 25 March, Gibson Craig 1400 tons (on charter) May, Serampore 1300 tons June, Cossipore 1250 tons July, Mirzapore 1250 tons July, Dinapore 1200 tons August, Caroline Chisholm 2500 tons September, Robert Lowe 2500 tons September, Alipore 1200 tons October, Barrackpore October. The Scotsman, 2 April 1853.

L. R. Fischer, "The Sale of the Century," The Northern Mariner, vol. V, no. 2 (April 1995), 35-46.

W. S. Lindsay \& Company Annual Circular, The Scotsman, 3 January 1855.

Graeme J Milne, Trade and Traders in Mid-Victorian Liverpool (Liverpool: Liverpool University Press, 2000).

LND/5/1-4 vol. 3: 8 and 10 .

W. H. Mitchell and L. A. Sawyer, The Cape Run (Lavenham: Terence Dalton, Ltd., 1984), viii. The ships were Robert Lowe, Tynemouth, England, Scotland, Ireland, James Hartley and W. S. Lindsay.

A. Muir and M. Davies, A Victorian Shipowner (London: Cayzer, Irvine and Co., 1978). 


\section{Three - Parliamentarian}

"the opportunity to charter steamers to the French government on particularly remunerative terms." 52

Since the 1840 s, Lindsay had worked from nine in the morning until seven at night and he now began to wonder what more he could do for others between seven and twelve pm. Describing himself as "a plain man [whose] business was his politics [with] a leaning towards Free-trade principals," ${ }^{23}$ he had taken a close interest in public affairs. He frequently addressed the Shipowners' Society and wrote many letters to the press and government about changes to the Navigation Laws which were published in a pamphlet in 1848. He decided to stand for Parliament, considering several constituencies, including Glasgow ${ }^{54}$ but stood unsuccessfully for Monmouth in April 1852 and Dartmouth in July. Finally, in March 1854, Lindsay was elected as member for Tynemouth and North Shields.

Lindsay supported Caroline Chisholm to found the Family Colonisation Loan Society in 1849 to champion British and Irish emigration to Australia. ${ }^{55}$ Known as the Emigrants' Friend, Mrs. Chisholm set up a private hostel in Deptford fitted out like a ship to acclimatise emigrants for the journey ahead. Her public comments on conditions onboard emigrant vessels had helped to pass the 1852 Passenger Act which Lindsay supported, and in return he arranged for 500 single females from the Jewish Ladies Benevolent Society to be carried to Australia in $1854 .{ }^{56} \mathrm{He}$ continued to support Mrs. Chisholm's work on behalf of female emigration and it is estimated that during the first half of the 1850 s between 5,000 and 6,000 young people travelled from London to Melbourne in Lindsay's ships. ${ }^{57}$

Lindsay's election to parliament coincided with the Crimean War and, having been chartering out his ships in the open market at twenty shillings per ton per month, he could now earn up to thirty-five shillings from the Admiralty. However, as a MP, he was barred from entering directly or indirectly into British Government contracts so instead chartered his sailing ships Alipore and Dinapore and steamers Robert Lowe and Tynemouth to the French Government at a more profitable sixty shillings per ton. The Admiralty asked again in November to charter his vessels and, despite claiming that he could earn $£ 35,000$ a year more from the French, he accepted an improved rate of fifty shillings per ton per month, circumventing the British Government's restrictions by

\section{$52 O D N B$.}

53 Lindsay, History of Merchant Shipping, 3: 208-209.

54 Kirkintilloch, UK, East Dunbartonshire Archives, GD185/8/5, Lindsay to Mackenzie, 14 February 1854.

55 Robin Haines, Life and Death in the Age of Sail (London: National Maritime Museum, 2006), 146.

56 Sir Charles Wood, Speeches, 13.

57 McKie, The Age. Mrs Chisholm died in Britain in obscurity in 1877. See also LND/5/1-4 vol. 3: 264-304. . 
exploiting the $64^{\text {th }}$ shares system. ${ }^{58}$

A curator's handwritten note on a random collection of fourteen bills of sale in Lindsay's papers describes them as "being more or less in the nature of day-to-day transaction in ships [and] have been regarded as not sufficiently important to index." 59 On the contrary, these bills illustrate the complex manner, not mentioned in his journal, in which Lindsay disguised the ownership of the vessels. On 28 December 1854, Lindsay signed a confidential memorandum of agreement with John Gladstone in which the four ships were chartered to Gladstone. Lindsay's 64 shares in Robert Lowe were transferred to his brother-in-law Robert Stewart (after serving three years as Lord Provost of Glasgow) and then to John Gladstone. The memorandum of agreement even provided that if Lindsay was "thrown in direct communication or action with the Government," he could act on Gladstone's behalf "as fully as Gladstone could act for himself." 60 In turn, Gladstone hired the vessels to the Lords Commissioners of the Admiralty as troop transports, on terms back-to-back with those agreed with Lindsay, and Gladstone received the hire of $£ 4,260$ per month gross as Lindsay's trustee. ${ }^{61}$

Lindsay calculated that sea transport services cost the British government $£ 15$ million during the "brief and unhappy war" from which he was drawing the equivalent of $£ 70,000$ per annum from the same source. Yet when the Admiralty delayed payment of running expenses he wrote a pamphlet about its mismanagement and founded the Administrative Reform Association on the grounds that the government's handling of the war had been inept. Not surprisingly, this created more enemies for him in Parliament. $^{62}$

In September 1854, Lindsay suffered what was possibly a minor stroke and went to Ryde on the Isle of Wight for one month to recuperate. Richard Cobden wrote to him:

You have succeeded beyond precedent for I doubt whether any body before achieved so much in private enterprise from 35 years of age as you have done. But it has been accomplished at the expense of some mischief to your brain...you must from this moment close your account with Fortune and [be] indifferent about the balance sheets at Austin Friars and the fame of W. S. Lindsay \& Co. Change your occupation! ${ }^{63}$

This last piece of advice was perhaps too radical for Lindsay, but the year 1855 had been successful for him in several respects. His shipbroking company chartered most of the French government's requirements for maritime transport in the Crimea and was rumoured to have about 90,000 tons of vessels under its sole management, of which 75,000 tons were steamers and the remainder were "the swiftest American clippers afloat." The half-year accounts for W. S. Lindsay \& Co. to 30 June 1855 show

58 NA, Register of Transactions, BT3/56-564/54.

59 LND/20 Bills of Sale.

$60 \mathrm{LND} / 21 \mathrm{MoA}$ for sale of shares between Lindsay and John Gladstone, 28 December 1854.

$61 \mathrm{LND} / 35 / 345$.

62 LND/5/1-4 vol. 3: 54, 88 and 92, vol. 4: 123 and 209.

63 LND/5/1-4 vol. 4: 249. 
earnings of $£ 80,724$ after depreciation on ships of $£ 10,272$. The last six months of 1855 were the company's most profitable ever, with brokerage from the French reaching $£ 20,000$, of which Lindsay’s personal share was $£ 8,000$. Added to earnings of $£ 30,000$ as a shipowner, the profit for 1855 , after depreciation, was $£ 76,000$. The dividend accounts indicate that Lindsay held shares, ranging from a few 64ths to a majority, in fifteen vessels and the expense accounts show he paid insurance and allowed depreciation of five percent on twelve. ${ }^{64}$

For the first time Lindsay ceased attending the office every day and, as he loosened his tight control of the company, Edgar Stringer gradually became the active partner. In August 1855, relishing his financial success, Lindsay bought "for amusement" a two-year-old eighty-foot steam yacht with a 10 horsepower engine which, when new, had cost $£ 2,500$ but he paid merely $£ 550$. The following month he sailed to Greenock and made a coastal tour of Scotland. He had not intended to build another ship but, believing in "living for others as well as ourselves," he gave his longserving Captain Dundas ten shares in an iron steamer from Laurence Hill of Port Glasgow expressly for him to command in the India trade and to "make a little independence for himself." ${ }^{65}$ September ended with Lindsay bidding for the 2,500-acre Exbury Estate in Hampshire for which the asking price was $£ 65,000$. Lindsay offered $£ 58,000$, which the sellers declined. ${ }^{66}$ In the House of Commons, Lindsay fought for maritime interests and promoted the development of steam power in ships. He wrote the minority opinion in the report of the Royal Commission of 1858-59 on manning the Royal Navy, proposing an increase in the size of the Royal Marine Corps on the grounds that "marines were the cream of England's servicemen." ${ }^{67}$ Fearing that his party's platform of reversing the policy of free-trade would be detrimental to British shipowners, Lindsay resigned his Tynemouth seat before the general election in April 1859 and was returned as member for Sunderland, which he represented until he retired in $1865 .^{68}$

Lindsay wrote to Russell on 9 November 1868, reminding him that it was twenty years since his series of letters to Russell giving plausible reasons against the repeal of the Navigation Laws. He admitted that only two years afterwards he discovered that not only were all his reasons erroneous but that Russell had known what was in the interest of shipowners better than the owners themselves. "What fools we shipowners were" he wrote, "and how much we ... have gained by your great and wise measure of repeal." 69

$64 \quad$ LND/5/1-4 vol. 4: 177-179, 219, 447, 455-457.

65 LND/5/1-4 vol. 4: 241, 257-279. At 225 feet long and with a $100 \mathrm{hp}$ engine, the price $£ 20,250$ was very cheap.

66 LND/5/1-4 vol 4: 283; 400 acres were woodland and the rest arable.

67 Wendel Calkins, Mariners Mirror 46 (1960), 65.

68 He was often referred to as member for Teignmouth or Sutherland: The Scotsman, 4 March 1859;. W. Brockie, Sunderland Notables (Sunderland: Hills and Co., 1894).

69 Lindsay to Russell, 9 November 1868 in Spencer Walpole, Life of Lord John Russell (n.p.: Elibron Classic, 2001), 3: 98. 


\section{Four - Diplomat}

"the infamous W. S. Lindsay of parliamentary and shipping notoriety...,"70

In 1860, the United States owned more shipping tonnage than Britain and Lindsay had developed strong business connections with many American shipowners. He planned a seven-thousand-mile tour through the North and Eastern States of America which was sanctioned by the United States but it was a delicate time for diplomacy and Lindsay stressed publicly that his mission was not in any official capacity. ${ }^{71}$ The foreign secretary, Lord John Russell gave him copies of official correspondence between the two nations concerning maritime issues and assured Lord Lyons, the British minister in Washington, that Lindsay "would not commit Her Majesty's Government to any opinion on international relations." 72 Nevertheless, a leading article in the Shipping Gazette, whose editor was a friend of Lindsay, announced "[he] goes to Washington at the instance of H. M. Government.",73

The Cunard steamship Europa sailed from Liverpool for Boston on 8 September 1860 and for the next three months Lindsay addressed nearly every chamber of commerce and board of trade as a man of business. With the shipping interest situated mainly in New York, he did not go further south than Washington where the contacts he made would soon be divided by the secession of the southern states, some entering the service of the new Confederate government, others remaining loyal to the Union. Lindsay spoke on the differences between British and American maritime statutory regulations ${ }^{74}$ and was described by an under secretary of state as "coldly arithmetical, one of those pestilential fellows who pin a man down to facts." 75 In New York, his visit was considered a failure because he had not openly expressed support for the North and therefore assumed to favour the South. ${ }^{76}$ Lindsay responded that as a member of the British government, if he had visited Charleston and other Southern ports, which he would have if time had allowed, his motives could have been wrongly construed. ${ }^{77}$

When Lindsay returned to England in January 1861, Russell publicly approved all that he had done. Lindsay began to speak regularly in Parliament about the prospect of an unfortunate war that he saw in commercial, legal and moral terms as much as in the division between North and South. He started corresponding regularly with prominent American politicians and in a reply to a personal letter from Alexander Duncan, a New York banker and member of the Peace Conference in Washington, Lindsay explained his

Official Records of Union and Confederate Navies in War of the Rebellion (hereinafter ORN) series 1, vol. 9 (Washington: Government Printing Office, 1899), 152-153, U.S. Secretary of the Navy Gideon Welles to Acting Rear-Admiral S. P. Lee, 14 August 1863.

71 The Times (London), 4 March 1860.

NA, Russell Papers, PRO 30/22/96 60, 63, Russell to Lyons, 22 August 1860.

The Scotsman, 13 September 1860.

Lindsay, History of Merchant Shipping, 3: 567-568.

LND/1 278.

New York Times, 4 January 1861.

LND/10 43. 
position in the growing political debate:

I look at history and consider the vast extent of your country and I find the interests of the South are opposed to the policy of the North. When I see that the two sections of your people differ in almost everything except language, and when I hear that they are resolved by the vote of several of their State legislatures to arm themselves and raise a vast army, not to coerce other States or attack the North but to defend themselves, I could not but feel that there must be a separation and that no force which the North could bring to bear will ever re-unite the Southern with the Northern States; but even if re-united by force of arms you could not treat them as a conquered people. That [was] contrary to the first principles of a Republican form of government. ${ }^{78}$

Lindsay believed that three-quarters of those living in the Northern states felt the Union could be restored by coercion and he foresaw a second and more terrible act in a rash drama. Ever the politician, he proposed what the North ought not to do: it should not march its armies into the South. Civil Wars had only one termination: there would be terrible bloodshed and the North would be further from its objective than when the carnage commenced. With the logic of a businessman, Lindsay concluded:

Separation would be easier now than after thousands of lives had been sacrificed and millions spent. Your country and commerce will be given a blow from which they will not recover in our generation. The good sense of your people and the spirit of justice which pervades their actions, will soon still their contentions when the sword is laid aside. $^{79}$

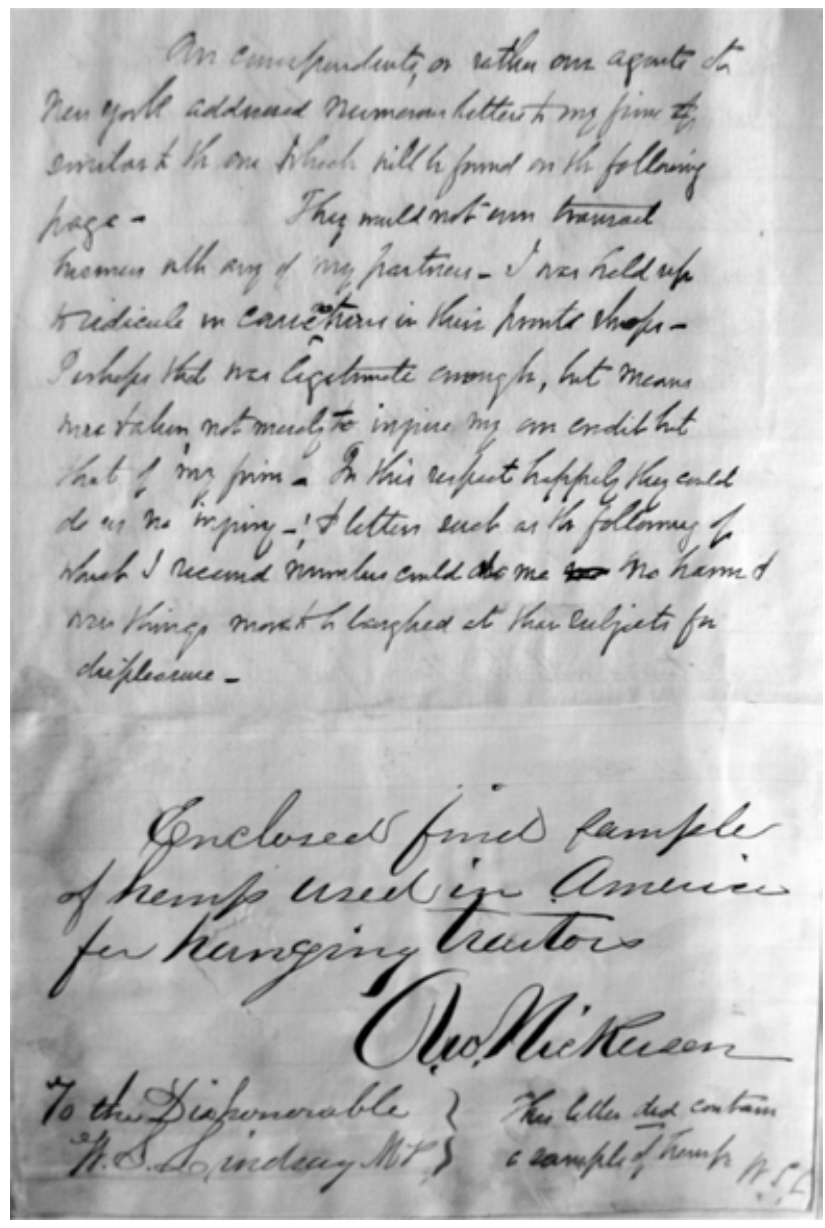

Illustration 3: for details, see illustration 4, opposite.

78 LND/7 25, reply to letter dated 24 March 1861 from bankers Duncan Sherman Company, New York. 
Somehow, Lindsay's private letter found its way into the New York press. Every Northern newspaper printed a leading article against him, angrily quoting his views, and he received a good deal of hate mail.

One abusive letter was addressed:

The dishonerable [sic] W.S. Lindsay MP: Enclosed find a sample of hemp used in America for hanging traitors. Tho. Nickersen.

An anonymous card pictured a chicken and a cauldron marked "tar" offering:

Feathers for sale - one shilling sterling. If Mr Lindsay will visit America again he will be furnished with a warm suit of clothes. ${ }^{80}$

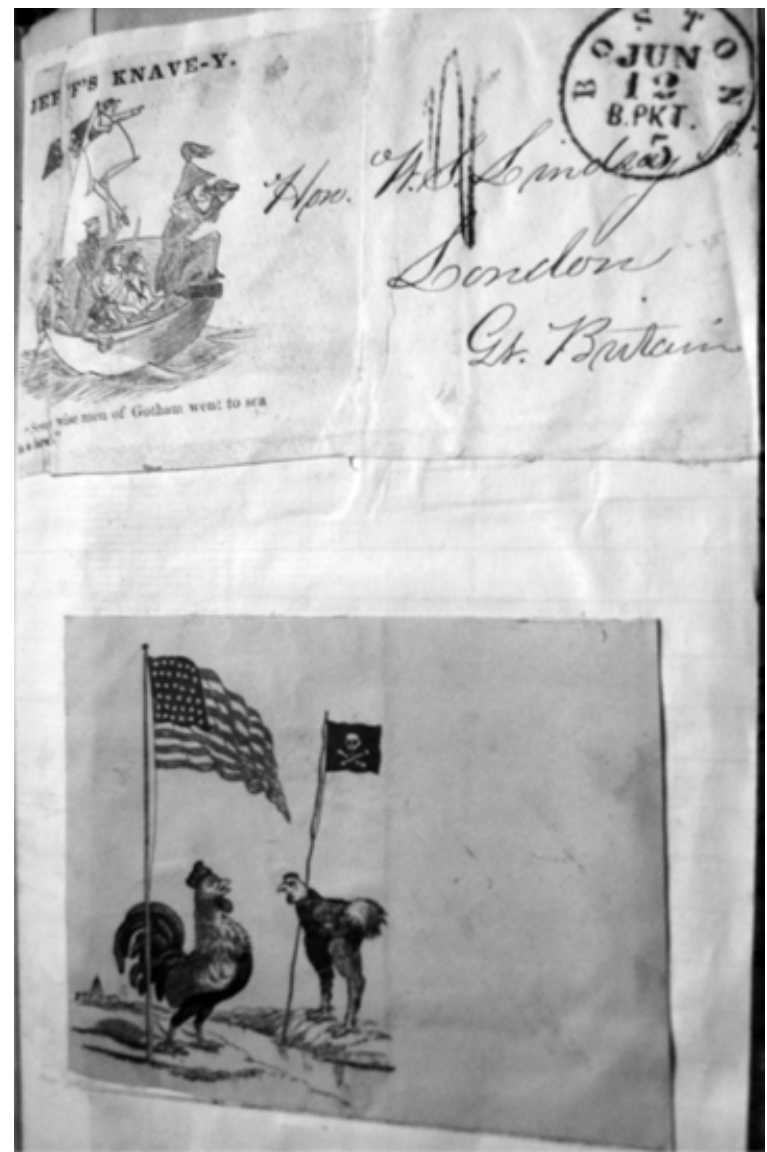

Illustration 4: Hate mail from the United States received by Lindsay after his letter of 24 March 1861 to the banker Alexander Duncan was published in the New York press. NMM, LND/7 letters 51 and 52. Credit: Author. See also illustrations 3 and 5.
Lindsay wryly acknowledged that he had created a great excitement on the other side of the Atlantic. Nevertheless, he continued to correspond with prominent diplomats and politicians in America and Europe, explaining his view that the true cause of the Southern secession movement was unjust taxation due to the selfish policy of the North and that, since the Confederates would never return to the Union, the war could only end in separation and therefore must be ended as soon as possible. In a new beginning the recently appointed Confederate Foreign Commissioner William Yancey arrived in London in July 1861 with a letter of introduction to Lindsay who invited him to meet the Members of Parliament in the Southern Lobby in the House of Commons. ${ }^{81}$

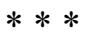

$80 \mathrm{LND} / 7$, letters 51 and 52.

81 J. D. Bennett, The London Confederates (Jefferson, NC: McFarland and Co., c. 2008), 28. 


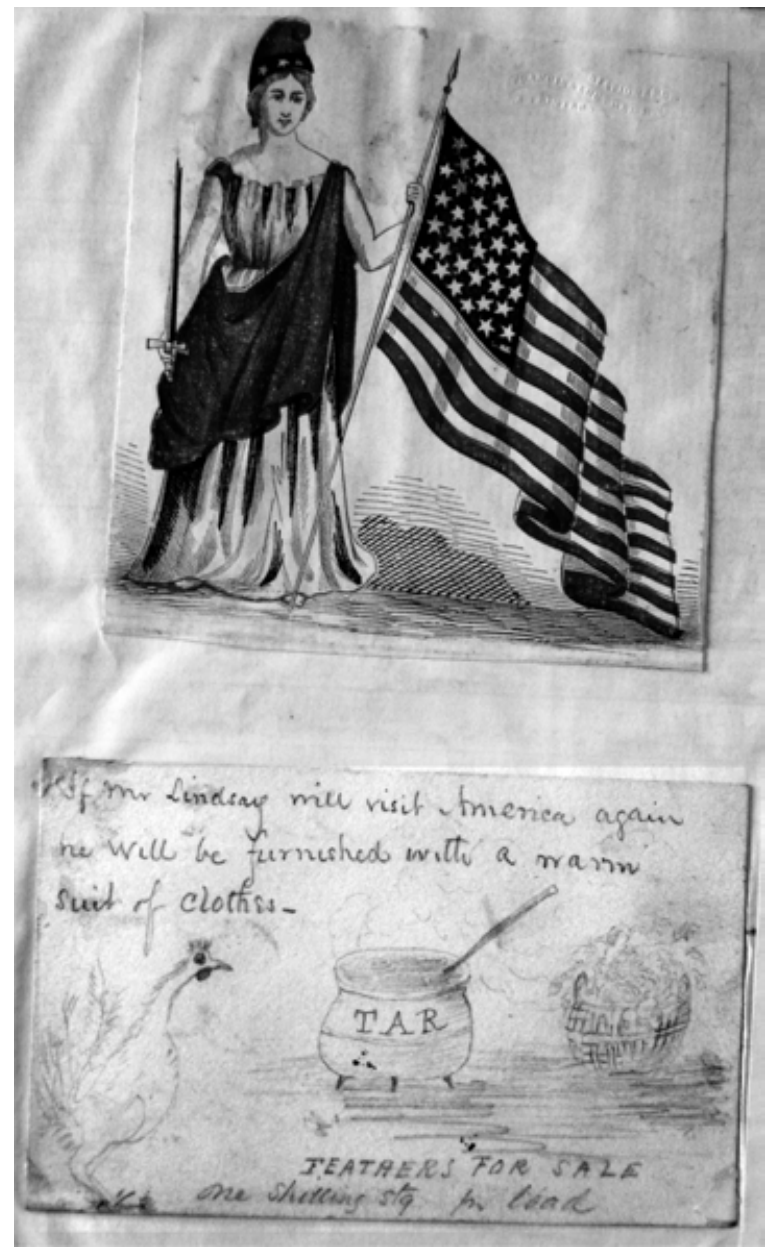

Illustration 5: for details, see illustration 4, previous page.
During that year Lord Russell sent Lindsay to Paris several times to discuss French enforcement of Navigation Laws. During these meetings, Lindsay developed a good relationship with the Emperor Napoleon III and was impressed by his wide knowledge of transport services during the Crimean war. ${ }^{82}$ The emperor remarked that the United States naval blockade, designed to prevent European merchants supplying strategic materials to the Confederate States in exchange for cotton, was losing France more trade than it was Britain, and therefore should not be respected. ${ }^{83} \mathrm{He}$ added that since the British ambassador to France, Lord Cowley, always dismissed French suggestions about the course they should take towards America, he had no faith in the official channels and any further meetings should be with Lindsay alone.

The first major debate in Parliament on the effectiveness of the U.S. naval blockade had taken place on 7 March 1862 when Lindsay proposed that Britain should remain strictly neutral. ${ }^{84}$ The following month Russell warned Cowley April that "Lindsay is becoming troublesome again," acting under Russell's instructions to avoid discussing the issue of the blockade, especially if it was hurting France more than Britain. Cowley certainly dismissed the emperor's comments as "a nasty intrigue" and described Lindsay's conversations with him (Cowley) as "full of hesitations [and] falsehoods hidden under apparent candour." He added that Lindsay told the emperor his own views, claiming they were supported by

82 Lindsay, History of Merchant Shipping, 3: 224, 440-443.

83 NA, Russell Papers, PRO 30/22/15 60-63, Russell to Lyons, 19 April 1862.

84 Hansard Parliamentary Debates, 7 March 1862.

85 NA, Russell Papers, PRO 30/22/105 95-100, Russell to Cowley, 14 April 1862.

86 Ephraim Douglas Adams Great Britain and the American Civil War (New York: Longmans, 1925), 2: 291. 
the majority of people in England and the opposition in Parliament. The emperor, aware of Cowley's open resentment of Lindsay's involvement in diplomacy, asked Lindsay to explain directly to Lords Russell, Palmerston and Derby and Mr. Disraeli that only joint action by Britain and France to dispatch a formidable fleet to the mouth of the Mississippi would end the war and give the South independence. ${ }^{87}$

Despite misgivings about upsetting the emperor, Russell sent a curt note to Lindsay dismissing his intervention:

As the Queen has an Ambassador at Paris and the Emperor an Ambassador in London, I think the best way for the two Governments to communicate with each other is through respective Embassies. I am sorry you have had so much trouble - I shall always be ready to listen to any message the Emperor will be pleased to send to the British Government either through Lord Cowley or the Count de Flahaut and to give such answers as the Cabinet may advise and the Queen approve. ${ }^{88}$

A chastened Lindsay offered to explain confidentially to Russell why the emperor had avoided the usual diplomatic channels but such a meeting was declined. Lindsay also failed to meet Palmerston and was partly rebuffed by Disraeli. Six days later, the emperor wrote to Cowley expressing his annoyance at Russell's rejection of Lindsay as an intermediary.

On 18 July 1862 Lindsay proposed a resolution in Parliament demanding that the government "make an offer of mediation to the contending parties in America for the sake of humanity." 89 Although the motion failed, it uncovered strong pro-South sentiment and not only in Parliament. ${ }^{90}$ A leader in The Times agreed that if a England, France and Russia united in recognising the Southern states, the North might pause "before the gulf opened [and] rendered a step taken in the interest of peace, an occasion of extending the war." 91 Lindsay published an open letter against the institution of slavery, asking the South to devise a way of abolishing it and undertook to broaden the base of popular support for Confederate causes in Britain. Since many people supported Southern selfdetermination, he also encouraged negotiations with the Great Powers of Europe to recognise the South's independence. ${ }^{92}$ Ever the shipowner, Lindsay noted that an article in the constitution of the nominally laissez-faire Confederate States required ships to pay duties for navigation lights, beacons and buoys, whereas the United States still offered these facilities gratuitously. ${ }^{93}$

Rumours in June 1863, that the emperor had decided France should not recognise

87 Owen F. Aldis, "Louis Napoleon and the Southern Confederacy," North American Review 129, no. 275 (1879), 342-361.

88 NA, MS 88/075, Russell to Lindsay, 24 April 1862.

89 Adams, Great Britain and the American Civil War, 301.

90 Hansard Parliamentary Debates, $4^{\text {th }}$ series, vol. 168, cols. 511-578, House of Commons, 18 July 1862; The Scotsman, 19 July 1862.

91 The Times (London), 21 July 1862.

$92 \mathrm{LND} / 1388$.

93 LND/36 letter 12. 
the South, coincided with Palmerston's announcement that the time for British recognition had not arrived. Lindsay travelled to Fontainebleau and was immediately granted an audience by the Emperor and the foreign minister, Drouyn de Lhuys, and both confirmed that France was still urging recognition of the Confederacy. ${ }^{94}$ In December, Lindsay, believing that the South could not be defeated, supported the formation of the Southern Independence Association in Britain whose 5,000 members kept the policy and justice of recognising the Confederacy in the public eye. Committee members included Lord Wharncliffe, James Spence, Alexander Collie, who, together with the banker Henry Schroder, contributed $£ 50$ to the British Jackson Monumental Fund to erect a seven foot statue of Confederate General Jackson in Richmond, Virginia (it was not unveiled until October 1875). ${ }^{95}$ Wharncliffe was also chairman of Alexander Collie \& Co. and the British press referred to the soon to be disgraced Collie as a leading blockade runner. ${ }^{96}$

In July 1864, Lindsay proposed yet another Parliamentary resolution in favour of recognition and mediation and "deeply regretting the great loss of life and the sufferings of the people of the United States and Confederate States of America by the continuance of the war." ${ }^{97}$ This was hardly a radical motion but to make it more acceptable to Washington, Lindsay suggested to Russell that the word "earliest" could be substituted by "most convenient" or even "most suitable." Russell still did not respond and many believed he was too willing to America's bidding and that his earlier refusal to express an opinion had misled the North to suppose that the Union could be re-established and thus had indirectly encouraged it to proceed. ${ }^{98}$ Faced with much opposition, the motions were withdrawn without a vote and there were many in Parliament who believed that a secret agreement already existed between Washington and Whitehall. ${ }^{99}$

\section{Five - The American Civil War Connection}

"his support for the Confederate states in the American Civil War, together with other maverick tendencies, caused some consternation among his supporters." 100

In what was to be his last speech in public, Lindsay addressed the Sunderland Shipowners Association and his constituents in August 1864 on his career as a free-trader. He explained that his interest in the United States began with its failure to reciprocate when Britain repealed the Navigation Laws in 1849. While he believed it was the duty of every thoughtful person to protest against the war still raging on the other side of the

94 ORN, ser. 2, vol. 3 (Washington: Government Printing Office, 1922), 814, J. A. Roebuck to Lindsay, 18 June 1863.

95 Richmond Daily Dispatch, 26 October 1875.

96 Sheffield City Library Archives, Wharncliffe Muniments, WhM 460/461, microfilm items 1/97 1863-1868, letters 87-89, 9 April 1868 (hereinafter WhM).

97 LND/1 420.

98 S. A. Goddard, Reply to Lindsay's Sunderland speech August 1864 (Birmingham, 1864), 3-16.

99 Frank Merli, Great Britain and the Confederate Navy 1865-1865 (Bloomington: Indiana University Press, 1970), 188.

100

$O D N B$. 
Atlantic, his position on putting an end to the conflict had been deliberately misunderstood. His concern for the Confederate cause was commercial and his prominent part in this issue was to protect the large class of people thrown out of employment in the manufacturing districts of Britain by the shortage of cotton from the Southern states. $\mathrm{He}$ had even dissolved business connections with those assisting the rebels and stated "If the Northerners were in earnest, as some of them profess to be, I would support them..."101

Nonetheless, Lindsay's well intentioned letters to the press and his speeches both in and out of Parliament on recognition of the Southern states as an independent nation had convinced the United States that he supported the rebellion politically and possibly financially and was intriguing with France to break the U.S. naval blockade. ${ }^{102}$ In fact, Lindsay had long since scaled back his activities. His health deteriorated between his mild stroke in 1854 and the paralytic stroke in 1864 that deprived him of the use of his legs. Although he continued to attend to his parliamentary duties, he officially retired from W. S. Lindsay \& Co. in $1862 .{ }^{103}$

It is clear that Edgar Stringer played a more active role in running both Lindsay $\&$ Co. and his own company, Stringer, Pembroke \& Co., as Lindsay's involvement diminished, and it was at around this same time that the U.S. accused Lindsay of breaking its naval blockade. The Rechid, formerly Sir Colin Campbell and the first iron steamer launched in Hartlepool in 1855, sailed from London on 18 December 1861, officially for Baltimore but sank en route with the loss of twenty-six crewmen. It was alleged that Lindsay was connected with the cargo and that if the blockade had been evaded, the voyage would have earned $£ 50,000 .{ }^{104}$

In early 1862 , George Sanders, a Virginian contractor, suggested to Confederate naval agent, James North that he should "see Lindsay MP and talk freely to him as he will appreciate our scheme more fully than any other man in England." ${ }^{105}$ Yet it was Stringer who introduced North to the Glasgow shipbuilder George Thomson and who rushed through the memorandum of agreement for an armour-clad steamship to be delivered by 1 June 1863 at a cost of $£ 182,000 .{ }^{106}$ The document was drawn up on 21 May 1862 and signed by Thomson and North with Stringer and James Galbraith as witnesses. The latter was an acknowledged blockade runner and chief partner of shipowners P. Henderson \& Co. and was named as North's lawyer. ${ }^{107}$ The nominal owner of the vessel was Edward Pembroke of Austin Friars, London and an agreement dated 17

101 LND/1 384-392, speech to Sunderland Shipowners Association, Lyceum Theatre, Sunderland, August 1864.

102 The Illustrated London News, 14 May 1864,470.

103 Lindsay, History of Merchant Shipping, 4: 462. His journal implies that he retired from the company in 1865 .

104 Peter Barton, "The First Blockade Runner and Another Alabama," Mariner's Mirror 81, no. 1 (February 1995), 53

105 ORN, ser. 2, vol. 2 (Washington: Government Printing Office, 1921), 220, G. N. Sanders, memorandum, n.d. [July 1862?].

106 Ibid., 182, J. H. North to G. Thomson, 11 April 1862.

107 Ibid., 199, memorandum of agreement, 21 May 1862. 
October transferred the title to Captain Sinclair of the Confederate Navy. On 11 November, North confirmed to Stephen Mallory, secretary of the navy at Richmond, that he had received "an offer of the most favourable kind' through William L Lindsay \& Co (sic) for the construction of a wood and iron vessel more powerful than Alabama." 108

At the end of November, a Confederate Captain Wilkinson wrote to Stringer from Funchal, Madeira, hoping "to repay some of the many obligations I owe your firm, individually and collectively." 109 However, Commander James Bulloch, the principal Confederate procurement agent in Europe, wrote to North regarding the selling price of cotton and warned him that "Mr E.P.S[tringer] is something more than sharp and I advise you to be cautious." ${ }^{\prime 10}$ Stringer's name appeared again in September when Bulloch wrote to Mallory that a Mr Stringer, with whom he was negotiating for the money to carry out his contract "wished me to sign bonds to the effect that the Confederate Government would pay for the ships in cotton on the basis of 8 cents per pound [instead] of at the market value of cotton [which] is much higher even now." 111

In November 1862, Lindsay became a close advisor to James M. Mason, the new Confederate States minister in London. Lindsay explained his plans to create a profitable post-war direct steamship line between Europe and Norfolk and New Orleans in partnership with the French Compagnie Générale Transatlantique and even offered to visit the South as soon as its ports were open. Mason recommended the project to his principals "as worth considering as the capital is large and in capable hands and has the aid and patronage of the French Emperor." 112 Unfortunately for Lindsay, the attention his company was now receiving resulted in a much higher public profile for him.

$$
* * *
$$

The Richmond Daily Dispatch published an undated and unsigned letter addressed to Mallory which appeared to have been sent in October 1862. It had either been hastily written or deliberately disguised and stated that Galbraith of Scotland and W. S. Lindsay \& Co., London were the houses with whom the writer had the negotiations about steamers. It asked that Captain Sinclair make preliminary contract arrangements by the writer's return for the construction at least one steamer for which Lindsay \& Co. would negotiate "the naval store bonds." 113

Next, the Princess Royal cleared London in December 1862 with "semi-military equipment" reportedly supplied by Lindsay \& Co. but was captured trying to enter Charleston harbour. The description of this ship and its voyage closely fit the Dolphin in Jules Verne's novella The Blockade Runners. ${ }^{114}$ Bulloch then warned North on 9 January

\footnotetext{
108 Ibid., 295-6, North to Mallory, 11 November 1862.

109 Ibid., 302, J. Wilkinson to Stringer, 25 November 1862.

110 Ibid., 323, Commander J .D. Bulloch to North, 28 December 1862.

111 Ibid., 277, Bulloch to Mallory, 24 September 1862.

112 ORN, ser. 2, 3: 592-593, J. M. Mason to J. P. Benjamin, 4 November 1862.

113 The Richmond Daily Dispatch, 24 January 1863.

114 Bennett, The London Confederates, 81; also Eric Graham, Clyde Built: Blockade Runners, Cruisers and Armoured Rams of the American Civil War (Edinburgh: Birlinn, 2006), 173.
} 
that his $£ 22,000$ cheque to Thomson would be the last for some time as his funds were exhausted but added:

It strikes me that W. S. Lindsay \& Co. ought to help you out with one payment at least without any security beyond your receipt for the money for I have understood that in consideration of the contract being made through them they would smooth away any difficulties that might occur. At any rate I would intimate to them something of the kind. $^{115}$

Within a few days a nervous Bulloch again asked if North had "made any effort with Messrs Lindsay \& Co., for the next payment."116 In March, funds to buy Georgia were secured from "the banking firm W. S. Lindsay" through the pro-Confederate Society for Promoting the Cessation of Hostilities in America of which Lindsay was secretary. ${ }^{117}$ However, after consulting Galbraith, North terminated the contract on 21 December 1863 on condition Thomson would not sell the ship to the Union Navy. ${ }^{118}$

After the Manchester Ordnance \& Rifle Co. wrote to North, care of Lindsay \& Co., to confirm an order for four 70-pounder muzzle-loading guns and ammunition, Manchester Ordnance acknowledged a cheque for $£ 1,710$ 18/-d which North had authorised Overend \& Gurney to issue. ${ }^{119}$ Stringer then claimed a $£ 1,000$ fee from arms suppliers Sinclair Hamilton \& Co. for introducing Nelson Clements, a Texas state agent, in March 1863. Slidell complained to Benjamin that "for this introduction to a seller of goods, the Confederate Government, the real purchaser, pays $£ 2,000$." ${ }^{120}$ Clements was in London to purchase 7,000 rifles, 2,840 muskets, 5,000 revolvers and sabres for the Confederate Army and pay with cotton. In May, Lindsay \& Co. chartered a schooner Caroline Goodyear to transport the arms to the port of Matamoros, Mexico and bring back the cotton. During the voyage, the ship was held in Vera Cruz and Earl Russell used his diplomatic skills with France to secure release of the cargo. ${ }^{121}$

Scott of Greenock's records showed that the 1858-built paddle-steamer Flora was bought in 1863 by W. S. Lindsay \& Co. for $£ 35,000, £ 3,000$ more than it cost new. ${ }^{122}$ There were also rumours that the Juno and Calypso were "fitted out by the infamous W. S. Lindsay ... or his shipping firm" and Flora was "heavily loaded [with] arms and

115 ORN, ser. 2, 2: 337, Bulloch to North, 9 January 1863.

116 Ibid., 343, Bulloch to North, 20 January 1863.

117 Bennett, The London Confederates, 148; Glasgow University Archive, UCS 1/11/1, Thomson to Lindsay \& Co., 29 October 1862 (two letters);. , ser, 2, 2: 295, North to Mallory, 11 November 1862; The Index, 25 March 1863.

118 ORN, ser. 2, 2: 326-329, "Memorandum of meeting between Messrs. Slidell, Mason, Barron, McRae and North, [December 1862?].

119 Ibid., 324, Manchester Ordnance Rifle to North c/o W S Lindsay \& Co., 30 December 1862.

120 ORN, ser. 2, 3: 933, John Slidell to Benjamin, 9 October 1863.

121 Ibid., 937-943, Slidell to Benjamin, 25 October 1863, with enclosures.

122 Johnson Robb, "Scotts of Greenock 1820-1920" (Unpublished PhD thesis, University of Glasgow, 1993), 174. The vessel was built for the Bristol General Steam Navigation Company. 
ammunition [and] the fastest running steamer in the British (sic) Channel." ${ }^{123}$ In fact it proved to be the Millwall-built screw steamship Flora but Lindsay \& Co. may have been the broker for the sale because this trio was employed by Alexander Collie.

At the end of August 1863, the Confederate secretary of the navy informed Bulloch in Paris that, in a secret act, Congress had appropriated $£ 2$ million for the construction of ships abroad and that the secretary of the treasury, being unable to supply the exchange, would issue cotton certificates in payment: "Mr H. E. [sic] Stringer now in Richmond, acting for W. S. Lindsay \& Co., made to me an offer to build vessels and to receive payment in certificates."124 Stringer and Pembroke were directors of the Mercantile Trading Co. with whom Colin McRae, the Confederacy's chief financial agent in Europe, had begun unproductive negotiations in April 1864 to acquire a number of steamers. In February 1864, Stringer, Collie and James Galbraith appeared with others before Lord Ormidale over the seizure of Pampero at Glasgow under the Foreign Enlistment Act but the Scottish court acted liberally and allowed the ship to remain in the hands of its owners but not to be used against belligerents.

In May, the steamer Pevensey ran aground at Wilmington, $\mathrm{NC}$ on its fourth blockade-running voyage. It had been despatched by Stringer, Pembroke \& Co. under a contract where ownership would be transferred to the Confederate government once the voyage profits exceeded the building costs. ${ }^{125}$ This vessel was linked to successful blockade-runners Atlanta, Juno and Charlotte, the latter also acquired by Mercantile Trading. Stringer had also invested in the now virtually bankrupt Alexander Collie \& Co. but Collie commented that he "heeded [Stringer] as little as the buzz of a mosquito: he meant mischief but had neither power nor influence to effect it." 126

Charles Adams, head of the United States legation in London, sent Lord Russell a list that indicated Lindsay owned twenty out of twenty-four named blockade runners. Lindsay protested he had not heard of these ships and, as an MP and a public man, he could not have ignored the proclamation of neutrality issued by Queen Victoria. He added that twelve months earlier when his shipbroking company was offered business with the Southern states and negotiated "one or two ships which could have run the blockade" he had told it to withdraw from the transaction despite having retired as head of the company the previous year. ${ }^{127}$

123 ORN, ser. 1, 9: 153, extract, consular dispatch from Bristol, England, 23 July 1863, forwarded by Welles to Rear-Admiral S.P. Lee, 14 August 1863 (my italics).

124 ORN, ser. 2, 2: 484, Mallory to Bulloch, 29 August 1863 (my italics).

125 ORN, ser. 1, vol. 10 (Washington: Government Printing Office, 1900), 136, 137, Acting Lieutenant T. A. Harris to Acting Rear-Admiral S .P. Lee, 16 June 1864.

126 Bennett, The London Confederates, 103, 107-108; Stringer to the chairman, Lord Wharncliffe, 9 April 1868 asking about the state of the company; also WhM 461, Collie to Wharncliffe, 27 June 1868. 


\section{Six - Cotton Speculator}

"Lindsay’s energy and driven personality were evident in all that he undertook.",128

In November 1862, Lindsay convinced James Mason to issue bonds on behalf of the Confederate government which would guarantee the payment of supplies after the war against future deliveries of cotton. Mason favoured Lindsay's plan because it could be adopted progressively and dropped at any time without heavily committing his government. Mason described Lindsay to Secretary of State Benjamin:

$\mathrm{He}$ is known as the largest shipowner in England, of the most extended commercial connection, and is trusted and consulted in commercial matters, as well by his own Government as by the Emperor of the French, an original and steady friend of the Southern States, and has been, for many years a member of Parliament. Through his house ... bonds for the delivery of cotton were negotiated to the amount of $£ 60,000$ sterling, for the use of the Navy Department ... The first issue of bonds should be for comparatively a small amount; say $£ 100,000$ sterling or, if desired, double that sum ... Indeed, Mr Lindsay told me I might say to the Government that, apart from other probable demands, he would undertake, through himself and connections, to furnish from a quarter to a half million of pounds sterling. ${ }^{129}$

In fact, Lindsay placed $£ 500,000$ worth of bonds, not on the market but through his company and personal connections alone. ${ }^{130} \mathrm{He}$ eventually raised $£ 898,000$ and the bond holders included Thomas Sterling Begbie, Alexander Collie, Lord Wharncliffe and the shipowner Fernie. ${ }^{131}$ Lindsay described his "very small investment" in the Confederate loan as being made "long after the loan was issued and years after my opinion in regard to the War in America had been expressed in and out of Parliament."132 However, as an emergency measure, the loan lacked foresight as it not only failed to consider the large amount of money that would be needed, but also the urgency of acting while the situation in the South justified the confidence of an investing public. ${ }^{133}$ It also made no allowance for reverses in the war and Lindsay saw little return on his investment.

Mason also reported that the business affairs of Lindsay \& Co. were chiefly managed by the other members of the firm and that Lindsay himself devoted most of his time to matters of more general and public interest connected with commerce. ${ }^{134}$

Were the rumours that Lindsay broke the U.S. Naval blockade justified? Henry Adams said it was Lindsay "about whom the whole web of rebel interests clung - rams, cruisers, munitions and Confederate loan - social introductions and parliamentary

$128 O D N B$.

129 ORN, ser. 2, 3, 590-592, Mason to Benjamin, 4 November 1862.

130 Richard I. Lester, Confederate Finance and Purchasing in Great Britain (Charlottesville: University Press of Virginia, 1975), 28-29.

131 Pall Mall Gazette, 30 October 1865.

132 The Times (London), 7 October 1865.

133 Lester, Confederate Finance, 29.

134 ORN, ser 2, vol. 3: 593, Mason to Benjamin, 4 November 1862. 
tactics. ${ }^{" 135}$ However, success in running the blockade depended on secrecy so the truth is difficult to find. As we have seen above, as early as 1862 Sanders suggested that North "talk freely to Lindsay MP," not Lindsay \& Co. but to the man himself. Similarly, in March 1863, the funds to buy Georgia came from the banking firm W. S. Lindsay through a pro-Confederate society of which Lindsay was an active member. While it may be unlikely that Lindsay supplied war materiel to the Confederate States to the same extent as his fellow Scottish-born merchants and shipowners, Collie, Begbie and Galbraith, a doubt must remain whether the Honourable Member of Parliament, who disguised the ownership of his vessels to obtain a lucrative government contract during the Crimean War, turned a blind eye to the blockade running activities of his partner, Edgar Stringer.

There is no record of the legal transfer of the ownership of W. S. Lindsay \& Co. but between 1865 and 1869 Lindsay received regular disbursement payments from Stringer, Pembroke \& Co. on his old ships Tynemouth and W. S. Lindsay and dividend cheques on their steamers Austin Friars and Woodham. ${ }^{136}$ In 1869, James Galbraith joined Stringer, Pembroke as senior partner in London and Glasgow and Pembroke, in turn, made payments to Sinclair, and Stringer, who had acted between "Lindsay Bank" and Commander North in financing Number 61, which was renamed Canton. ${ }^{137}$

In retirement, Lindsay improved his estate at The Manor House, Shepperton which he purchased in 1856, acquiring the lordship of the manor in the process. He owned several other estates including the manor of Halliford, lands and farms at Hailsham and Chertsey, and was involved in the construction of the Thames Valley Railway. The census of 1871 described him as a shipowner and landowner and he was a prolific author of articles, poetry, books and a journal that he described as "the log of a leisure moment for they have been written at times and at various places [and] are truly the work of my idle hours." ${ }^{\text {"138 }}$ Government ministers and public figures visited him to seek advice and he collected newspaper cuttings on business and politics and corresponded with friends and contacts, including Disraeli, Russell, Gladstone and David Livingstone. His continuing interest in American maritime affairs and the Civil War is reflected in his post-war letters with former leading Confederates expressing regret that "the Southern people who fought so nobly and so well" were not able to achieve the independence of the Confederate States. ${ }^{139}$

William Schaw Lindsay died at Staines on 28 August 1877 at the age of sixty-one after a fatal stroke which was blamed on overwork. Shortly before, he had been planning to visits ships in Southampton and Glasgow and in the later pages of his journal he

135 Henry Adams, The Education of Henry Adams (1918; repr., Boston, 1961), 186

136 LND/22, bank cheques received by Lindsay, 1865-69.

137 Stringer remained with Galbraith, Stringer, Pembroke \& Co., 8 Austin Friars, London for another 10 years and died in Brighton in 1894. Galbraiths is still a leading London shipbroker.

138 LND/5/1-4, vol. 1; The Log of my Leisure Hours by an old sailor was described by a contemporary newspaper as "one of the best boys' book we know": LND/3/1-8 vol. 3: 58.

139

LND/35/1-6 vol. 2: 124. 


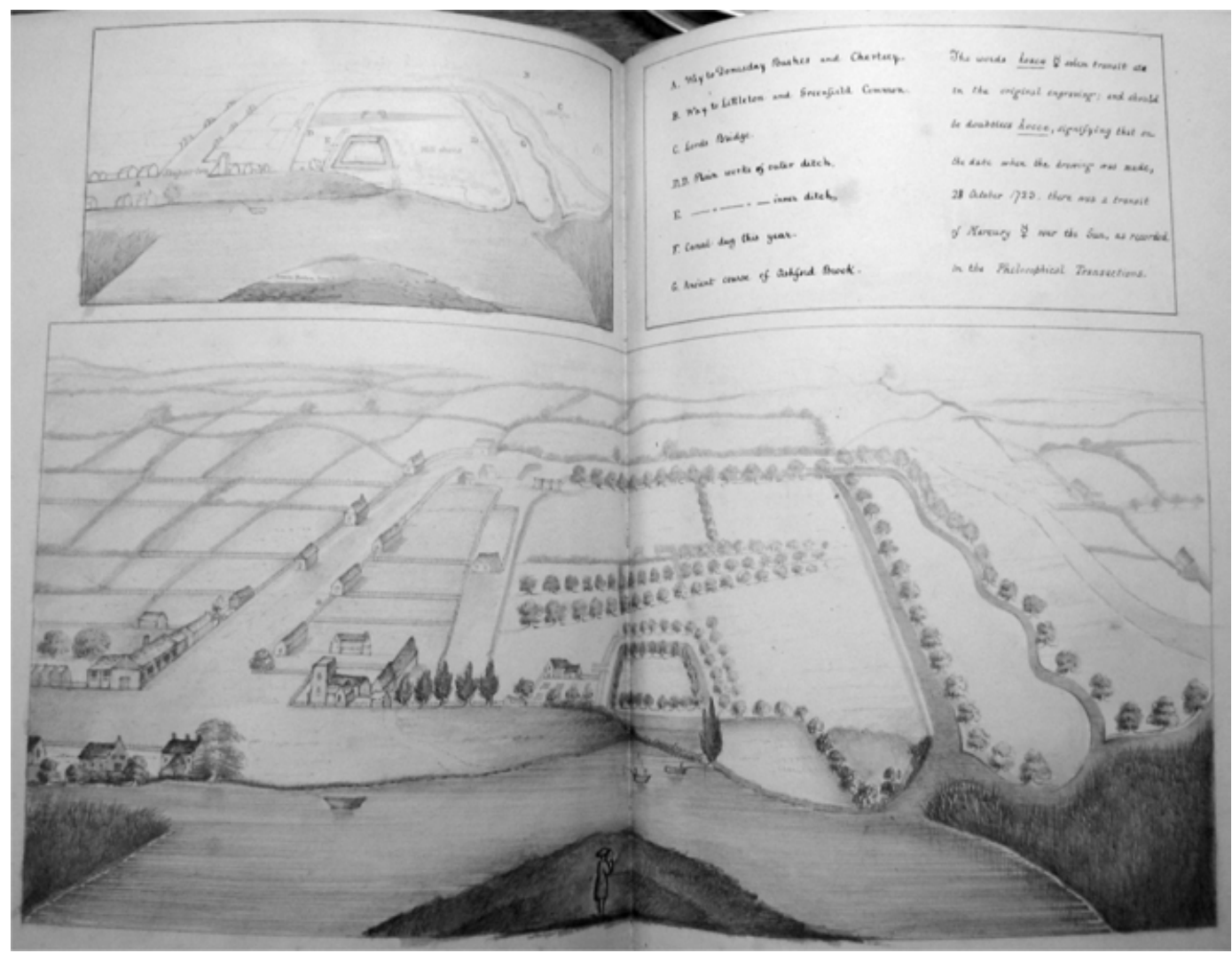

Illustration 6: Lindsay's plans for improving Shepperton Manor. Sketch undated but probably made shortly after he acquired the estate circa 1860. NMM, LND5/4 558. Credit: Author.

reminisced about his old school friends and shipmates. ${ }^{140}$ The press calculated that his wealth was less than $£ 45,000$, hardly the fortune of a merchant prince. ${ }^{141}$

\section{The Final Chapter of an Old Sailor}

"He fictionalised many of his experiences..."142

Lindsay's obituary in The Scotsman 30 August 1877 noted that he made many friends and never lost one but we now know that many of his activities were misrepresented by some of the enemies he had created. Yet his description of business contemporaries, such as Allan, Willcox and Anderson above, reflects a common theme to how he saw his own life:

140 LND/5/1-4 vol. 4: 461, 465-478, 551 and 893.

141 Glasgow Herald, Greenock Telegraph, Clyde Shipping Gazette, all for 29 August 1877; Shipping \& Mercantile Gazette, 30 August 1877; The Times, Sunderland Times, 31 August 1877. Probate granted 29 September 1877. 
They were plodding and industrious and consequently overcame every difficulty, ensuring the success that industry and economy must ever command. Allan's industry was unwearied, his love for truth ever conspicuous and with the most unassuming and pleasing manners. His only failing consisted in believing all other men to be as upright as himself. Willcox was a young man with no influence and but limited pecuniary means, who opened his own office in London and commenced business on his own account as a shipbroker. Anderson's only capital was a plain but sound education, good moral and Christian training, a clear head and great industry. ${ }^{143}$

The Presbyterian work ethic and moral code instilled by the Reverend William Schaw who took him in and educated him, was also important. In a eulogic essay, The Good Old Parson, Lindsay described Schaw as "a life-long good relation and the best friend that ever I had."

In 1865, Lindsay contemplated his ascent from cabin boy to shipbroker and shipowner and to unparallelled prosperity:

Little indeed did I imagine when a poor and friendless boy on the forecastle of the Isabella that a course of industry, honesty and perseverance would, under the beneficent Disposer of my destiny, realise the results which I have now to record. Since that time I may say I have had no assistance from my fellow men. No rich friend, or relative, has bequeathed me capital to advance me in life. No one has in any degree substantially promoted my welfare: and therefore the results are the more astonishing. They even strike me with surprise, though I have risen step by step, I have become enriched by degrees. ${ }^{144}$

Perhaps the best clue to how Lindsay viewed his achievements is found in his 1868 novel — The Log of My Leisure Hours — under the pseudonym "An Old Sailor." In volume three, the business career of the fictional hero Richard Claremont, a thinly disguised Lindsay, is summed up with more emotion than the author ever showed in his journals:

He now took rank amongst the first in his line of business in the great city. He had gained his position by a course of industry, and by a rigid adherence to sound commercial principles. Avoiding speculation in every form, he confined himself to commissions; and as his capital accumulated, which it did with great rapidity, for at that time he did not spend one-tenth of his income, he invested it in what he understood. His attendance at the office was constant and regular; sitting in the midst of his clerks, he not only set them an example of punctuality, but he saw that the business was properly attended to. He endeavoured also to maintain a uniform system — saw every letter received was courteously answered in course of post and that the sailor's wife was as promptly replied to as the wife or clerk of the great shipowners who entrusted him with the consignment of their vessels. Nor would he allow any irregularity or laxity in the conduct of his business, even to merchants whose affluence might have been of much value to him.

143 Lindsay, History of Merchant Shipping, 4:378n1 and n2, 381n 1.

144 LND/5/1-4, vol. 4: 447. The 1851 Census described him shipowner, merchant and Member of Parliament living at The Manor House, Shepperton, Middlesex with his wife and son and 10 servants. 


\section{Appendix One}

The Oxford Dictionary of National Biography has for long wrongly repeated that William Schaw Lindsay's family details are sketchy. His parents, Joseph Lindsay and Mary Belch, married on 26 August 1798 in Stirling. He was born on 19 December 1815, Christened on 1 May 1816 and was their youngest child. The eldest, Peter Belch Lindsay, was born 16 January 1801, Alexander on 11 November 1802, Helen in 1808 and Mary, whose birth date in unclear. Alexander died in 1820, and in 1828 Helen married Thomas Christie, twenty years her senior and a writer in Glasgow and had a son and three daughters. Mary married the Reverend John McKerrow of Bridge of Teith, a Secession Minister at Doune, Stirling and the author of the History of the Secession Church (1841), the standard work for all seceders in Scotland.

A few months before Lindsay's birth, his father's business had failed and successive speculative misfortunes had plunged him into despair. Later the family moved to Glasgow where his mother furnished a house and let out rooms to lodgers. Alcoholism undermined his father's health and he died in 1819 followed in 1825, after a decade of struggling against poverty to keep up a respectable appearance, by the death of Lindsay's mother in 1825 .

William Schaw Lindsay's childless aunt and uncle took him into the manse where he was born. The Reverend Schaw arranged a place for him at Ayr Academy in the hope that he would become a Free Church minister like himself. Lindsay recalled that he seldom reached the top of his form but excelled at "leaping and running and using my fists" and described Schaw as "a life-long good relation and the best friend that ever I had." $" 145$..

In 1831, aged fifteen, Lindsay headed for Glasgow in the hope that his brother Peter would provide him with a home and employment but Peter's wife made him feel unwelcome. Both died circa 1835 in miserable circumstances: Peter a "half-witted fool through intemperance and debauchery," his wife "raving mad in a fit of delirium tremens from excessive drinking." ${ }^{146}$ His sister, Helen, who also resided in Glasgow, agreed to shelter him and he willingly entered her husband's counting house. However, he did not take to the business of a writer and, since he realised it was unlikely he could enter one of the professions, he decided it was time to look after himself. On 14 November 1843, William Schaw Lindsay married Helen Stewart in Glasgow and their son William Stewart Lindsay was born in 1849 in London ${ }^{147}$ and died in Timaru, New Zealand on 28 June 1924. In 1881 Helen was still living at the Manor House, Shepperton with five servants and the lease was held by Edward Pembroke of 8 Austin Friars. She died in 1890, aged 70 at Christchurch, Hants and her trustee was the Reverend John McKerrow of Penicuick, Midlothian, her late husband's brother-in-law.

Lindsay was a prolific letter writer and speechmaker on politics and maritime subjects and kept a journal between 1855 and 1867. His papers, some 2,000 items

145 LND/19, The Good Old Parson.

146 LND/5/1-4 vol. 1: 221-3.

147 Ibid., 301. 
including a typescript commissioned by the Lindsay family and made by Mrs Hilda M. Kirkwood, ${ }^{148}$ were acquired at Sotheby's by the National Maritime Museum in Greenwich in July $1988 .{ }^{149}$

\section{Appendix Two}

\section{Lindsay's shareholdings in vessels $1850-1865^{150}$}

Alipore 1,350 tons built Sunderland 1850. 64/64 $4^{\text {th }}$ (Bill of Sale (BoS) $1 / 2 / 1851$ transferred $36 / 64^{\text {th }}$ to others and on $27 / 4 / 185428 / 64^{\text {th }}$ to J. Gladstone).

Barrakpore built Sunderland $185064 / 64^{\text {th }}$ (BoS $1 / 2 / 185132 / 64^{\text {th }}$ transfers to others).

Cossipore 707 tons built Dundee $185126 / 64^{\text {th }}$ (38/64 ${ }^{\text {th }}$ held by others including master) Lloyds Register names W. S. Lindsay \& Co. as owner from 1852 to 1863.

Dinapore 1,350 tons built Workington $185130 / 64^{\text {th }}\left(34 / 64^{\text {th }}\right.$ held by others incl. master).

England built Glasgow $185622 / 64^{\text {th }}\left(32 / 64^{\text {th }}\right.$ Dundas, $10 / 64^{\text {th }}$ Brown) Lloyds names W.S.L. Co. owners to 1860 and vessel sold to Japan in 1862.

Helen Lindsay Sunderland $185030 / 64^{\text {th }}$ (Lloyds names Lindsay owner, BoS of 26/3/1853 transferred to H. Brown then in 1858 to Bonus \& Co. till 1860).

Ireland built Hartlepool 1852 64/64 (sold in 1858 and renamed Don Pedro).

Mirzapore built Birkenhead 1844. Lloyds names McDonald, Liverpool as owners between 1850 and 1860 .

Nile 347 tons built $18502 / 64^{\text {th }}$ (balance held by James Moss, Lamport \& Holt) Sold to Dublin 1853 and Lloyds names Duncan Dunbar as owner from 1855.

Orontes 347 tons built Clyde $18512 / 64^{\text {th }}\left(185232 / 64^{\text {th }}\right.$ owned by Lamport \& Holt).

Robert Lowe built Greenock $185464 / 64^{\text {th }}$ Lloyds names Lindsay as owner until 1859 in Far East tea trade (transferred Gladstone \& Stewart).

Scamander 753 tons built $18544 / 64^{\text {th }}$ (balance held by Alfred Holt and others).

Scotland built Port Glasgow $185643 / 64^{\text {th }}\left(21 / 64^{\text {th }}\right.$ A. Adamson) Lloyds names Lindsay as owner to 1860 in China tea trade, then sold to Far East in 1862.

Shooting Star built Nova Scotia 1854 Lloyds names Lindsay \& Co owners until 1860 when sold to Wm. Currie.

Tynemouth built Newcastle 1854. Lloyds names Lindsay owner till 1865 and he probably held all $64 / 64^{\text {th }}$.

W. S. Lindsay built Northumberland $185254 / 64^{\text {th }}, 10 / 64^{\text {th }}$ master.

$148 \mathrm{LND} / 35 / 1-6$.

149 Mariner's Mirror 75 (1989), 254.

150 NA, Register of Transactions, BT3/56-564/54, BT107/102, 103, 104 and 107, BT108/1, 2 and 3. 
Unidentified holdings or charters possibly linked to W.S.L. ${ }^{151}$

Arctic

Calypso built 1861

Canton renamed Pampero. W.S.Lindsay \& Co. helped arrange finance.

Clarendon built Newcastle 1855. Lloyds names Leslie \& Co as owners 1856.

Coromandel* blt Greenock 1843. Ewing, L'pool owns to 1860 thence Ogden, Liverpool.

Fire Cracker

Gladiator* built Sunderland 1851. Lloyds names owners Blyth \& Co., London.

Hugh Lindsay built 1829 India for the East India Co.

James L Bogart built 1851 America Grinnell's Swallow Tail Line to New York 1855.

Jenny Lind* built Sunderland 1847 Lloyds names owners Blyth Green to 1864.

Juno either built Hull 1861 owner Wilson to 1863 or if Sunderland 1854 Egglestone, Sunderland.

Mary Stewart built Sunderland 1847 owners Aitken \& Co. Greenock to 1864.

Moultan* built Hartlepool 1849 Lindsay thence Thomson \& Co., London.

Newcastle built Sunderland 1854 Middle Dock, Newcastle.

Pactolus* built Sunderland 1852 owner S. Turney, London (Lamport \& Holt?).

Sir Colin Campbell built Hartlepool 1855 owner R. Young and renamed Rachid 1862.

Tally $\mathrm{Ho}^{*}$

Undine built 1857 Cartsdyke (Lamport \& Holt).

* W.S.L. \& Co received dividends or paid insurance on these vessels in June and/or December 1855 which may have been in its role as a shipbroker. Note the majority were built in North East yards where Lindsay was MP.

151 LND/5/1-4 vol. 4: 177-179, 219, 447, 455-457. 


\section{AWARDS PRESENTED BY}

\section{THE NORTH AMERICAN SOCIETY FOR OCEANIC HISTORY}

\section{THE JOHN LYMAN BOOK AWARDS}

Each year NASOH presents the John Lyman Book Awards to recognize excellence in the publication of books which make significant contributions to the study and understanding of maritime and naval history. Books are honored in multiple categories of maritime and naval history. The award is named in honor of John Lyman (1921-1977), oceanographer, maritime historian, and a founder of NASOH.

\section{THE K. JACK BAUER AWARD}

In 1988, NASOH created the K. Jack Bauer Award to honor those who have given distinguished service to $\mathrm{NASOH}$ and who have made life-time contributions to the field of maritime history. The award is named in honor of E. Jack Bauer (1926-1987), naval historian and founder of the NASOH.

\section{CHAD SMITH STUDENT TRAVEL GRANTS}

$\mathrm{NASOH}$ provides funds to assist students in funding travel to its annual meeting to deliver a paper at the meeting. The award is named in honor of Philip Chadwick Foster Smith, maritime museum curator, maritime historian, and an early member of NASOH.

\section{CLARK G. REYNOLDS BEST STUDENT PAPER AWARD} conference.

Each year NASOH honors the student who presents the best paper at its annual

$$
* \ldots *
$$

All award winners are normally announced at the banquet held in conjunction with NASOH's annual conference which is usually held in May. Inquiries concerning eligibility and application procedures can be directed to:

$\begin{array}{llll}\text { John Lyman } & \text { Dr. Gene Allen Smith } & \text { Other } & \text { James C. Bradford } \\ \text { Book Awards: } & \text { Department of History } & \text { Awards: } & \text { Department of History } \\ & \text { TCU Box 297260 } & & \text { Texas A\&M University } \\ \text { 2800 University Drive } & & \text { College Station, TX 77843- } \\ & \text { Fort Worth, TX 76129 } & 4236 \\ \text { Telephone: 817/257-6295 } & \text { Telephone: } 979-845-7165, \text { or } \\ \text { E-mail: G.Smith@tcu.edu } & \text { 979-775-5448 } \\ & & \text { E-mail: jcbradford@tamu.edu }\end{array}$

